\title{
29. TEXTURAL AND MINERALOGICAL RELATIONS OF BASALTS FROM SITES 100 and 105
}

\author{
W. B. Bryan, Woods Hole Oceanographic Institution, Woods Hole, Mass.
}

\section{INTRODUCTION}

Basalts cored from Sites 100 and 105 are of particular interest as they occur beneath sedimentary rocks of early Mesozoic age. If these are true basement rocks, they must represent some of the oldest sea floor material so far sampled, and may provide important clues to volcanic processes along the mid-Atlantic Ridge during early stages of the opening of the ocean basin. On the other hand, if the basalts are intrusive into the sedimentary rocks, as some of the evidence suggests, they may conceal an older portion of the stratigraphic record which is of unknown duration. Also, these two basalt cores are among the longest and most complete of those so far recovered in the DSDP program, so they provide an opportunity to observe the depth and degree of alteration and other textural and mineralogical variations to an extent not previously possible.

The present investigation was restricted to detailed examination of polished thin sections in both reflected and transmitted light. For Site 100, these included both remounted and polished sections originally prepared on shipboard, and new sections prepared from chips of basalt taken from other intervals in the core.

Studies of core from Site 105 were restricted to thin sections prepared on shipboard, several of which were polished and remounted. Silicate mineral identifications and compositions are based upon color, birefringence, relief, and optic angle or extinction angles, but are necessarily tentative due to difficulties imposed by fine grain-size, alteration and, in the case of feldspars, the generally poor development of albite twinning. Opaque oxides were identified by color and reflectivity in reflected light; observations were again restricted by the fine grain-size and very incomplete crystalline development of the oxide minerals.

Fresh basalt samples from the two sites can, in general, be distinguished by textural differences; those from Site 100 typically consist of randomly oriented plagioclase microlites with intergranular pyroxene, while samples from Site 105 are characterized by plumose intergrowths of plagioclase and augite.

At both sites, the basalt cores contain numerous inclusions or thin partings of calcareous sedimentary rock which appear indurated, but show little evidence of recrystallization when viewed in thin section. These indicate that at least a thin veneer of sedimentary material had been deposited before the basalts were erupted, and they would therefore not be appreciably older than the overlying sediment. Both cores are highly fractured; especially the core from Site 105, and the fractures are filled with carbonate. Glassy zones and selvages are apparently also more common in the basalt from Site 105. This, along with the textural differences, suggests that the basalt at Site 100 may represent one or two relatively massive basalt layers, while the basalt at Site 105 would appear to represent a sequence of thin flow sheets or lava pillows.

\section{BASALT FROM SITE 100}

At Site 100 the drill penetrated basalt to a depth of 6.2 meters, of which about 4.4 meters were recovered. A thin glass selvage at the top surface of the basalt could be interpreted both as a chill zone against the overlying limestone or as a result of chilling against seawater.

Samples from Cores 11 and 12 appear to have been very similar in texture and primary mineralogy, the most important difference being the degree of alteration in the pyroxenes and fine-grained groundmass. Plagioclase has crystallized as randomly oriented laths averaging about 0.1 millimeter in length. These are only rarely twinned on the albite law, and carlsbad twinning is also rare. The few extinction angles measured indicated compositions of $\mathrm{An}_{50}-\mathrm{An}_{70}$. The pyroxene typically occurs as granules interstitial to the network of plagioclase laths. It often shows optical strain and incomplete extinction suggestive of an hour-glass pattern. The optic angle is variable but is always of positive sign, suggesting compositions ranging between pigeonite and sub-calcic augite. Magnetite invariably occurs with a skeletal, cruciform habit and is always a groundmass phase.

Some of the fresher samples show a feathery groundmass texture in which microlites of plagioclase and pyroxene radiate from a central plagioclase lath which serves as the "spine" of the feather. Magnetite crystallites tend to be concentrated along the outer margins of these pyroxene-plagioclase feathers. The mineral paragenesis suggested by these relations are thus: plagioclase, plagioclase plus pyroxene, and finally magnetite. 
Samples from Core 13 differ slightly in texture, being characterized by relatively coarse patches of pyroxene and plagioclase. In these, plagioclase laths may be up to 0.5 millimeter in length and tend to form radial clusters which protrude from a core of pyroxene granules. The pyroxene, again, shows moderate birefringence and a small to moderate optic angle, and is probably pigeonitic augite. Quenched portions of the groundmass show feathery intergrowths of plagioclase and pyroxene similar to those observed in Cores 11 and 12. Elsewhere, the groundmass shows an intergranular texture similar to that described above. The coarser patches observed in Core 13 may represent incipient development of areas of gabbroic pegmatite which represent areas of more efficient crystal growth induced by a combination of slower cooling and water, or other vapor trapped below the chilled crust.

Alteration to palagonite, chlorite and carbonate is common throughout Cores 11, 12 and 13. Alteration preferentially attacks glass, fine groundmass intergrowths, and pyroxene in order of susceptibility. The larger plagioclase laths are usually clear and free of visible alteration effects, although a few become turbid and show development of sericite and clay minerals. Carbonate is common as vug and fracture fillings and as granules throughout the altered groundmass.

\section{BASALT FROM SITE 105}

A total of 10.8 meters of basalt was cored at the bottom of the hole, of which 8.7 meters of core were recovered. The uppermost chill zone directly beneath the sedimentary cover consists of altered glass containing a few fresh sheaf-life aggregates of acicular plagioclase. This merges downward into a slightly less altered zone in which there are traces of a feathery pyroxeneplagioclase intergrowth. This texture is best displayed in a fresh sample 3.2 meters below the top of the basalt core. The thin section shows scattered rounded phenocrysts and microphenocrysts of plagioclase. Spinel, reddish-brown in transmitted light, forms rare octahedral microphenocrysts. Most of the rock is composed of intimately intergrown plagioclase and pyroxene which form feathery or plumose aggregates (Figure 1).

The plagioclase phenocrysts are of uniform composition, about $\mathrm{An}_{80}$, except for a narrow overgrowth normally zoned to $\mathrm{An}_{35-40}$. Groundmass plagioclase averages about $\mathrm{An}_{50}$, but is also zoned to more sodic compositions. The habit of these crystals is strongly acicular, being elongated along the $a$ direction. Many of these are hollow, especially toward the ends of the crystals, and enclose tiny granules of pyroxene and magnetite (Figure 2).

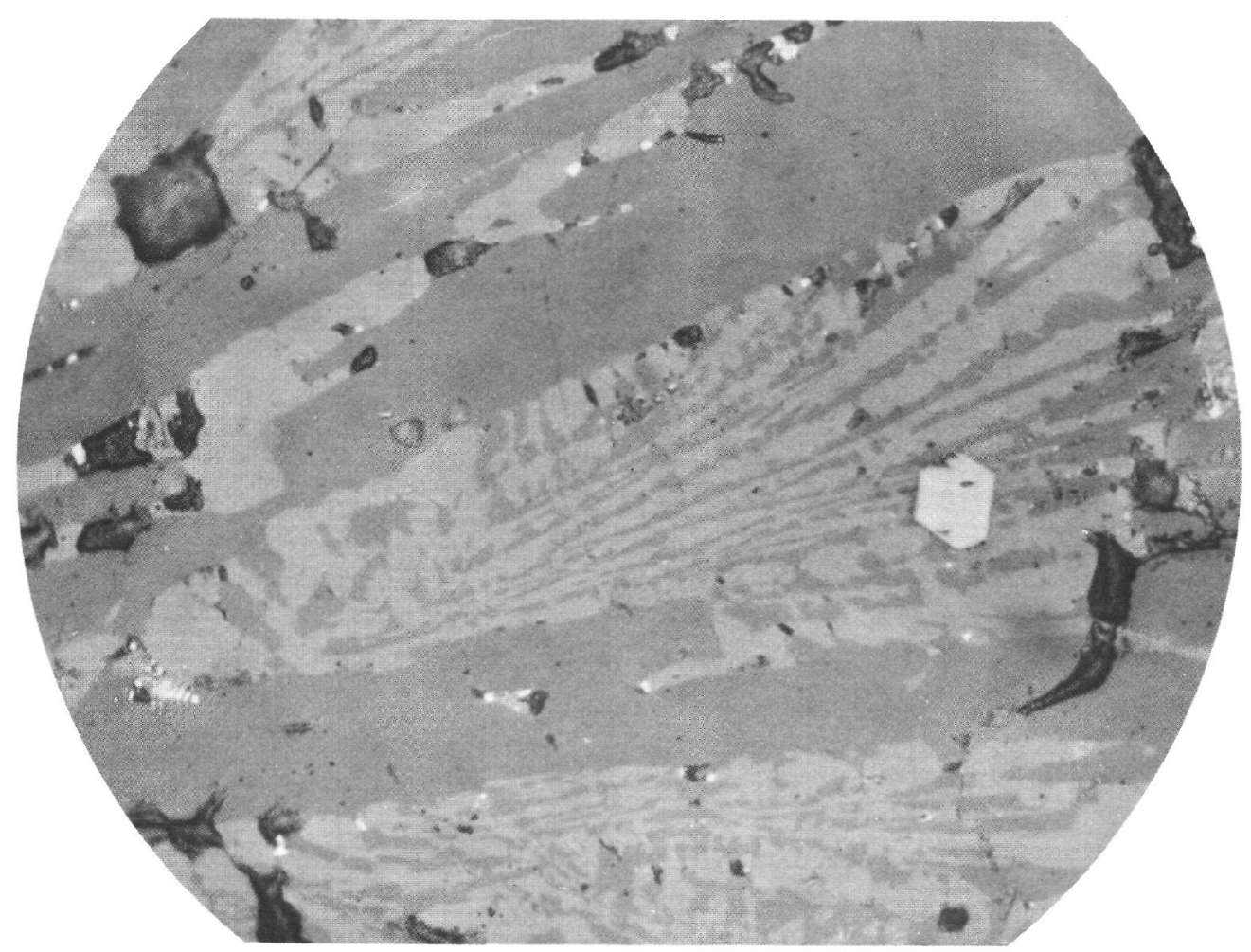

Figure 1. Site 105. Basalt 3.2 meters below sediment interface. Euhedral spinel (white) enclosed by plumose intergrowth of pyroxene (light gray) and plagioclase (dark gray). Larger dark gray areas are plagioclase microlites. Reflected light, magnification 400X. 


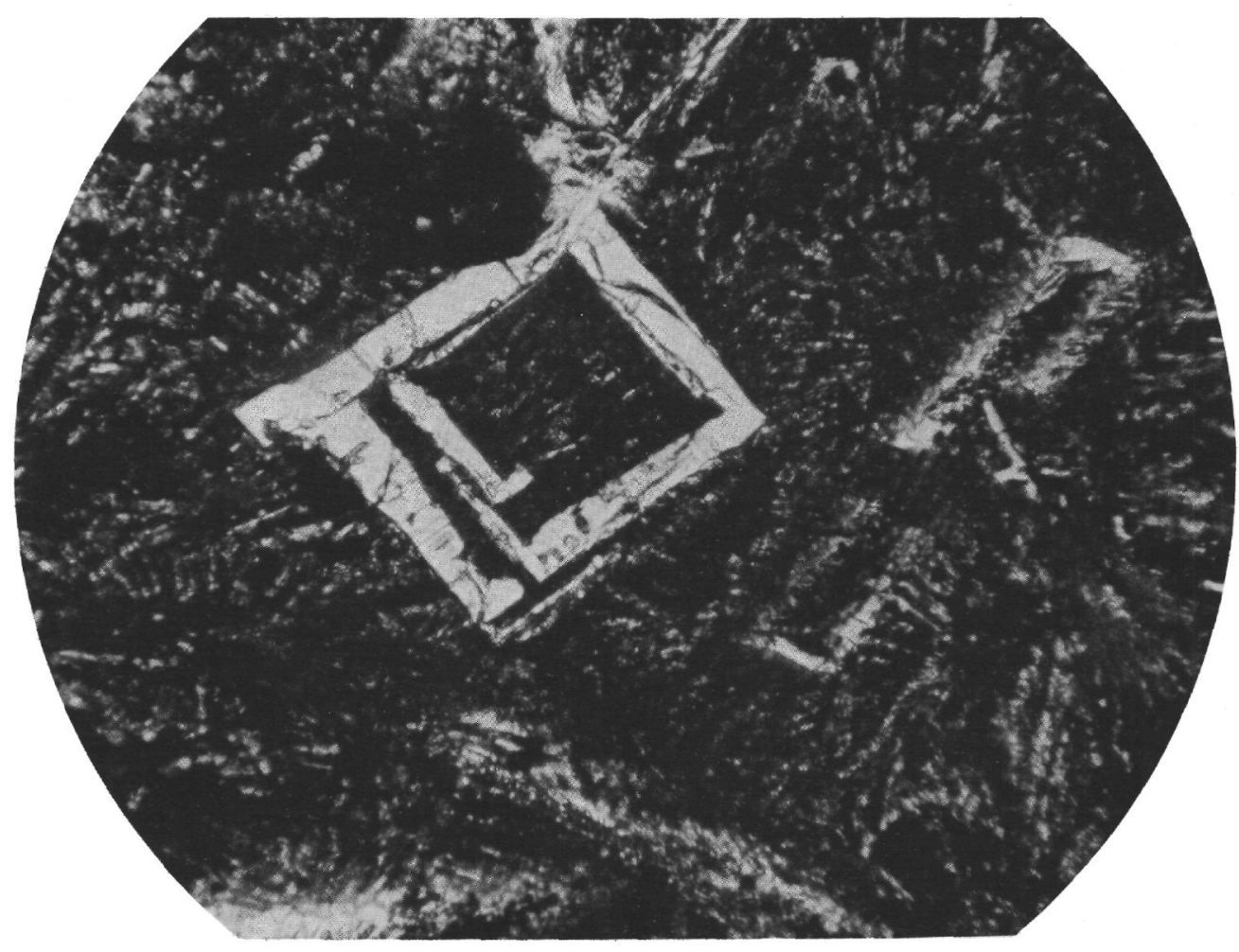

Figure 2. Site 105. Basalt 3.2 meters below sediment interface. Plagioclase (white) viewed approximately along a axis forms square prism enclosing intergrown pyroxene and feldspar. Another hollow plagioclase appears to the right in an oblique section. Dark background is complex intergrowth of plagioclase and pyroxene with minor magnetite. Transmitted light, magnification 100X.

Magnetite appears as overgrowths on spinel, where the latter is enclosed by plumose pyroxene-plagioclase intergrowths, and also forms cruciform skeletal crystals in these areas. Magnetite overgrowths are absent from spinels enclosed by plagioclase microphenocrysts. Olivine was not observed in the thin section, but an area of chlorite and iddingsite has a typical olivine outline and may be an olivine pseudomorph. Olivine does not appear in the groundmass.

A core catcher sample from the base of the hole (10.8 meters) shows the same textural and mineralogical features already described, except that it appears to be more rapidly quenched than the sample at 3.2 meters. Here, as in the quenched samples directly below the sediment interface at the top of the hole, magnetite shows a very incipient development near the outer margins of the plagioclase-pyroxene intergrowths. There is again a large, rounded plagioclase phenocryst, an olivine pseudomorph, and a few small octahedra of spinel.

The mineral paragenesis indicated by these relations is: olivine-spinel, plagioclase, plagioclase-augite, magnetite. Secondary minerals include chlorite, clay, and hematite replacing fine-grained plagioclase-pyroxene intergrowths. Carbonate fills vesicles and fractures, but is not common even in the most altered areas of groundmass.

\section{SIGNIFICANCE OF MINERALOGICAL AND TEXTURAL DATA}

The observations reported here are of a preliminary nature, and detailed interpretation and conclusions would clearly be premature. Nevertheless, certain of the features observed appear to have important implications for the petrogenesis of these basalts and also for their geologic relationships and magnetic properties.

\section{Classification}

The absence of olivine at Site 100, and its appearance only as a rare phenocryst phase in basalt at Site 105 indicate that these basalts are almost saturated or over-saturated with silica. The pigeonitic augite and the groundmass iron-enrichment indicated by late crystallization of magnetite are also characteristic of saturated or over-saturated subalkaline basalts. In this respect 
they are similar to other subalkaline basalts of the present mid-ocean ridges, and appear unrelated to the alkali-olivine basalts which are common on oceanic islands.

\section{Textures}

The feathery pyroxene-plagioclase intergrowths and clusters found in these basalts are also typical of quenched basalts currently under study by the author from the mid-Atlantic Ridge. Similar textures were also described and illustrated by Muir and Tilley (1966) in basalts dredged on the mid-Atlantic Ridge near $30^{\circ} \mathrm{N}$, and they reached similar conclusions about the paragenesis of the major silicate minerals. Thus, the basalts at Sites 100 and 105 do not differ texturally in any important respect from samples dredged from surface outcrops along the Ridge, and could thus have been erupted and crystallized under conditions similar to those now prevailing in or near the median valley.

\section{Mineral Paragenesis and Magnetic Properties}

In the basalts from Sites 100 and 105 magnetite invariably crystallizes late and is a skeletal-groundmass phase in the more holocrystalline samples. It is rare or absent in the more rapidly quenched samples, apparently remaining in solution in the groundmass glass. As magnetite is the mineral responsible for most, if not all, of the magnetic signature of seafloor basalts, its quantity, composition, and the degree of crystal development may have important effects on the magnetic properties of the basalt. Carmichael (1970), p. 247) has commented on the anomalously weak magnetization of a largely glassy sample of basalt collected west of the median valley at $45^{\circ} 39^{\prime}$ North. He also noted that NRM dropped off rapidly away from the median valley and considered the possibility that this reflected variations in the quantity and composition of magnetite, but his data are inconclusive on this point. If, as he suggests, a layer of fine-grained basalt a few tens of meters thick accounts for most of the magnetic signature of the sea floor, the intensity and hardness of that signature may be very much dependent upon subtle differences in the nature and rate of the eruptive process at any given time. It is clear that rapid quenching may inhibit the formation of all or most of the magnetite potentially present in the magma, and that the glass and very fine-grained magnetite in such rocks may be especially susceptible to later alteration and oxidation which would destroy much of the magnetic record. If the uppermost basalt layers represent flank flows or later intrusive sills interspersed with sedimentary rock, they may have a polarity different from the older basement basalts. It appears that the magnetic 'smooth zone' on the margins of the Atlantic may reflect these complicating factors to varying degrees. The limited data from Sites 100 and 105, which lie within this zone in the Western Atlantic, suggest that the predominance of very fine or glassy basalt extending to depths of at least 8 to 10 meters, extensive devitrification and alteration also extending at least to these depths, and the possibility of a long period of both intrusive and extrusive igneous activity-punctuated by at least one brief period of sedimentation-may all contribute to the weak magnetic signature in this area.

\section{REFERENCES}

Carmichael, C. M., 1970. The mid-Atlantic Ridge near $45^{\circ} \mathrm{N}$. VII. Magnetic properties and opaque mineralogy of dredged samples. Can. J. Earth Sci. 7, 239.

Muir, I. D. and Tilley, C. E., 1966. Basalts from the northern part of the mid-Atlantic Ridge II. The Atlantis collections near $30^{\circ}$ N. J. Petrol. 7, 193. 